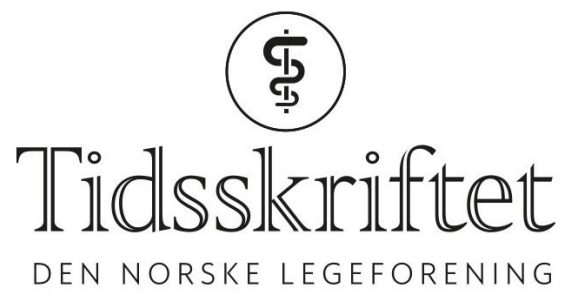

\title{
Fritt frem for kunnskapssvake medisinstudenter
}

\author{
DEBATT \\ VIDAR M. STEEN \\ E-post: vidar.martin.steen@helse-bergen.no \\ Vidar M. Steen er professor ved Klinisk institutt 2 ved Universitetet i Bergen, der han er \\ undervisningsleder i medisinsk genetikk og medlem av terminstyret for 9. termin ved \\ profesjonsstudiet i medisin. Han er også FoU-overlege ved Avdeling for medisinsk genetikk ved \\ Haukeland universitetssjukehus. \\ Forfatter har fylt ut ICMJE-skjemaet og oppgir ingen interessekonflikter.
}

Det er i dag fullt mulig å avgi eksamensbesvarelser med kliniske vurderinger som åpenbart ville ført til alvorlig helseskade hos pasienten, og likevel bestå.

Skriftlig eksamen er en viktig del av kvalitetssikringen som sørger for at vi utdanner kvalifiserte leger. Fungerer den skriftlige eksamensordningen i medisinstudiet med tanke på å fremme ønsket læring og samtidig fange opp de riktige strykkandidatene blant det lille mindretallet av kunnskapssvake og potensielt «farlige» studenter?

Deler av temaet ble nylig drøftet i Petter Gjersviks kronikk Eksamenslcere for dummies (1). Der ble mange av mulighetene og utfordringene med dagens digitale eksamener tatt opp, med omtale av fordeler og ulemper ved flervalgsoppgaver versus kortsvarsoppgaver med fritekst. Gjersvik oppsummerte at "... [h] ensikten med eksamen i medisinstudiet er at samfunn, helsevesen og pasienter skal være sikre på at universitetene utdanner leger som duger».

Jeg er sterkt i tvil om dagens eksamensordning svarer til denne hensikten. Det gjelder særlig det å skulle dokumentere at studentene har oppnådd tilfredsstillende kunnskap og tilhørende ferdigheter på alle essensielle fagområder samt sjekke at de har noenlunde kontroll på hva de kan - og minst like viktig hva de ikke kan, når de senere som leger skal treffe beslutninger i klinisk praksis.

Hovedproblemet er ikke bare knyttet til selve oppgaveformen - flervalgsoppgaver eller kortsvarsoppgaver - men minst like mye hvordan den overordnete sensureringen av disse utøves

Hovedproblemet er ikke bare knyttet til selve oppgaveformen - flervalgsoppgaver eller kortsvarsoppgaver - men minst like mye hvordan den overordnete sensureringen av disse utøves. Utfordringen kom til syne for meg etter innføringen av ny studieplan for medisinstudiet i Bergen i 2015, med langt mer integrert undervisning mellom mange fag og en samleeksamen i hver termin. Denne omleggingen har hatt flere positive effekter, og tilsvarende ordninger med store termin- eller årseksamener som omfatter mange ulike fag, 
er også godt innarbeidet ved andre medisinske læresteder, blant annet Norges teknisknaturvitenskapelige universitet i Trondheim, der fagmiljøene har argumentert for bruken av en forhåndsbestemt beståttgrense på $65 \%$ som standard for hvilke studenter som skal passere nåløyet (2).

\section{Eksamenssensuren siler ikke godt nok}

Likevel mener jeg at vi i altfor liten grad har tatt høyde for de negative konsekvensene av å teste mange fag og tema på en gang, noe som særlig rammer mindre fag. Medisinsk genetikk hadde for eksempel tidligere en separat totimers skriftlig eksamen, der hver student måtte dokumentere en viss minimumskunnskap i faget for å bestå. I den nye studieplanen utgjør dette fagområdet omkring 10-15\% av en sekstimers skriftlig, digital eksamen for 9. termin, med totalt 150 poeng, vanligvis fordelt på omkring 90 ettpoengs flervalgsoppgaver (6o \%) med fire svaralternativer og 6o poeng ( $40 \%$ ) på ulike kortsvarsoppgaver. Det gis en samlet karakter på skalaen A-F (A er best og F er stryk), og den relative strykgrensen ligger ofte omkring 6o \% av maksimal poengskår. Det er ikke anledning til å gi særskilt vurdering av et enkelt fagområde eller en undergruppe av spørsmål.

Jeg mener at vi i altfor liten grad har tatt høyde for de negative konsekvensene av å teste mange fag og tema på en gang, noe som særlig rammer mindre fag

En student kan altså levere en meget svak besvarelse i alle spørsmålene som gjelder medisinsk genetikk eller et hvilket som helst viktig tema og likevel bestå eksamen. Studenten kan også i sin eksamensbesvarelse gjøre kliniske vurderinger og foreslå tiltak som med høy sannsynlighet ville ført til alvorlig helseskade eller endog fatalt utfall hos pasienten, uten at det fører til stryk. Det er en ubehagelig følelse å være med på å godkjenne en slik eksamenssensur. Liknende erfaringer er gjort av kollegaer som underviser i andre kliniske terminer. Vi benytter altså ikke muligheten til å sette på bremsene for studenter som gjør uakseptable feil, som tilsvarer det å kjøre mot kjøreretningen eller overse vikeplikten på den praktiske førerprøven.

\section{Løsningen er enkel}

Det er heldigvis kun et fåtall studenter som svikter grovt. De aller fleste studenter er kunnskapsrike og dyktige, ofte veldig dyktige. Og det finnes minst én mulig løsning. Den skriftlige, digitale eksamenen bør deles i to. Del A kan utgjøre rundt $20-25 \%$ av eksamen, med oppgaver som utelukkende tester helt essensiell kunnskap, altså fakta og vurderinger som faglærerne er enige om at alle studentene må beherske. Poengene i del A skal inngå i totalskåren, og det gis fortsatt bare en samlet karakter på eksamen. Men det skal være et tilleggskrav: Det tillates knapt nok feil på del A utover det å gi et visst slingringsmonn for potensielle "glipp» med feilavkryssning. På en gitt eksamen kan alle fagområdene i terminen være representert blant disse kjernespørsmålene. Dermed vil det bli langt vanskeligere å bestå eksamen for studenter som har viktige kunnskapsmangler som følge av bevisst utelatelse av å sette seg inn i enkelte tema eller av andre årsaker.

Jeg mener vi har mye å vinne på en slik justering av eksamen. Det vil presse underviserne til å diskutere og vurdere særskilt nøye hva som er den essensielle kunnskapen på deres felt, noe som over tid vil definere kjernen i de ulike fagområdene. Det vil også motivere studentene til bred læring og bidra til at vi utdanner leger som duger faglig på alle viktige felt, i tråd med samfunnsoppdraget vårt.

1. Gjersvik P. Eksamenslære for dummies. Tidsskr Nor Legeforen 2020; 140. doi: 10.4045/tidsskr.20.0142.

[PubMed][CrossRef] 
2. Colberg AB, Vatn D, Standal R et al. Hvordan kan strykprosenten ved eksamen stabiliseres? Tidsskr Nor Legeforen 2017; 137. doi: 10.4045/tidsskr.17.0947. [PubMed][CrossRef]

Publisert: 9. november 2020. Tidsskr Nor Legeforen. DOI: 10.4045/tidsskr.20.0733

Mottatt 14.9.2020, godkjent 14.10.2020.

(C) Tidsskrift for Den norske legeforening 2020. Lastet ned fra tidsskriftet.no 